\title{
Harvesting orchard pruning residues in southern Piedmont: a first evaluation of biomass production and harvest loss
}

\author{
Marco Grella, Marco Manzone, Fabrizio Gioelli, Paolo Balsari \\ Department of Agricultural, Forest and Food Sciences (DISAFA), University of Turin, Italy
}

\begin{abstract}
In recent years, interest in farming residues has grown and orchard pruning residues are no exception. Several factors define pruned branch mass and dimensional characteristics: fruit variety, vigor, training system used, and pruning intensity and periodicity. While many studies have been performed to determine residue biomass availability, dating and surveying are not always accurate. Detailed qualitative and quantitative knowledge is needed to evaluate the economic sustainability of exploiting orchard pruning residues as an energy source. To assess the real chain potential of renewable energy production from orchard pruning residues in the area of Cuneo, in the Region of Piedmont, northwestern Italy, a study was conducted on the species Actinidia (kiwi tree) pruned according to the Peyracchia system, and Malus (apple tree) pruned according to two different systems, i.e. traditional and taille longue. For each species, pruning residue amounts were quantified and their basal diameter measured. Surveys were performed on some half trees, spaced as crop, for three randomised replications. Pruning residues were determined by dynamometer (accuracy 0.02N); individual cut-off branch diameters were measured at their base with mechanical calipers. Pruning residues were blown by rotating rake and harvested by a modified fixed chamber round baler. Harvest losses were determined by the methodology used for the initial residue quantification. Results showed the
\end{abstract}

Correspondence: Marco Grella, Department of Agricultural, Forest and Food Sciences (DISAFA), University of Turin, via Leonardo da Vinci 44, 10095 Grugliasco (T0), Italy.

Tel. +39.011 .6708610 - Fax: +39.011 .6708591 .

E-mail: marco.grella@unito.it

Key words: biomass, harvest, losses, orchard, pruning.

Contributions: MG and MM data collection and analysis; MG wrote the manuscript and searched for references; FG and PB reviewed the manuscript; PB planned the research.

Conflict of interest: the authors declare no conflicts of interest.

Received for publication: 12 June 2013.

Accepted for publication: 23 September 2013.

(C) Copyright M. Grella et al., 2013

Licensee PAGEPress, Italy

Journal of Agricultural Engineering 2013; XLIV:e14

doi:10.4081/jae.2013.e14

This article is distributed under the terms of the Creative Commons Attribution Noncommercial License (by-nc 3.0) which permits any noncommercial use, distribution, and reproduction in any medium, provided the original author(s) and source are credited. average biomass availability was $2.51 \mathrm{Mg} \mathrm{DM} \mathrm{ha}^{-1}$ (SD 0.83) for kiwi tree, 3.04 $\mathrm{Mg} \mathrm{DM} \mathrm{ha}^{-1}$ (SD 1.17) for traditionally-pruned apple trees, and $0.46 \mathrm{Mg} \mathrm{DM} \mathrm{ha}^{-1}$ (SD 0.36) for apple trees pruned with the taille longue system. Harvest losses (total pruned dry mass) averaged approximately $19 \%$ in kiwi trees and $16 \%$ in apple trees (95\% to $10 \%$ for variety).

\section{Introduction}

The context of the national energy scenario is such that alternatively sourced production processes are of fundamental interest and importance, especially in the light of two opposing factors. The first is compliance with the so-called climate-energy package 20-20-20 or EC Directive 2009/29. This sets the objective of reducing greenhouse gas emissions by $20 \%$ by increasing the share of energy produced from renewable sources to $20 \%$ and achieving a $20 \%$ energy savings, all by 2020. The second is to address the growing energy demand with the development of an organic policy. These commitments mean that Italy must urgently assess the current use of potential renewable energy sources, including biomasses as defined by article 2 of Legislative Decree no. 387 of 29 December 2003.

Agriculture is one of the main suppliers of renewable solid fuels.

Although Italian agricolture sector has not super-productive crops (short rotation forestry) specifically dedicated to this purpose (Biomasse Italia S.p.A., 2008; Manzone, 2006) the agricultural sector provides a diverse array of biomasses that ranges from herbaceous energy crops to wood, dedicated to residual production. The main problem with energy from biomass enhancement is related to difficulties of supply.

In agriculture, orchard pruning residues, olive trees, and vines are the primary residual woody biomass components (ENAMA, 2011). These biomasses are cut and generally lie on top of the soil between tree rows. Alternatively, they are harvested and burned alongside the rows, with the subsequent risk of parasitic infestation and fire (Tyson et al., 2012). In addition, their management represents a huge cost for farmers (Cotana et al., 2008). Nevertheless, energy production from such wastes may solve the problem of their disposal and reduce farm management costs as routine shredding operations of the pruning residues are replaced by income from the harvest, such that the revenue received at least covers the cost of the harvest.

Several studies (CNR, 2012; ENAMA, 2011; ENEA, 2010; ISTAT, 2010; ITABIA, 2005) have been conducted on the physical characteristics and availability of biomass and biofuels. Yield of agricultural residues is generally determined by multiplying the cultivated surface with residue productivity coefficients (CESTAAT, 1990). However, the resulting information is often too general and not site-specific. Orchard heterogeneity demands timely and up-dated surveys on residual biomass availability. Fruit farming in Piedmont has changed completely in just a few decades. Family-run orchards are now run on industrial lines and this is reflected in their size. Advanced pruning 
and training techniques are adopted, and farmers draw on the latest scientific knowledge on cultivar and selected rootstock. These changes were aimed at achieving higher production quality and quantity, but have contributed to the reduction in pruning biomass from smaller and less vigorous trees.

Ongoing issues affecting orchard farming must be taken into account if a precise evaluation of the supply chain is to be made. Bacterial actinidia is currently plaguing kiwi trees and is expected to drastically reduce the biomass availability in the Cuneo area (CReSO, 2011). Bacterial actinidia is a disease with high phytosanitary risk caused by the bacterium Pseudomonas syringae pv. actinidiae. This was first reported in Piedmont in 2010 and spread rapidly with particular virulence. The disease limits the vigour of the plant; it causes the branches to dry out and brings on early tree death. Although research is underway, no remedy has yet been found. In the Piedmont area, previously unscathed areas are now affected (Quadretti, 2013). Quite recently (8 April 2013), the Region of Piedmont approved a plan to implement emergency measures (Resolution 251, Regione Piemonte, 2013). This essentially involves prohibiting new kiwi planting and imposes specific measures to avoid the disease spreading.

With these considerations in mind, our work had a double focus related to the quantitative availability and measurement and characterisation of orchard pruning biomass. The first goal was to understand the real potential of orchard pruning biomass as a bioenergy solid fuel supply chain, and the second goal was to quantify harvest losses relative to dimension (basal diameter) of cut branches.

This work is part of a larger project, Energy from the orchard: an example of supply chain for the production of renewable energy from orchards pruning (FRUITGAS), funded by the European Union within Measure 124 of the Rural Development Programme (F.E.A.S.R. 2007/2013 - CHALLENGES "HEALTH CHECK"), and carried out at two representative orchard farms located near to each other in the Province of Cuneo (CN) in the Region of Piedmont, northwestern Italy.

\section{Materials and methods}

Two species of fruit tree were considered in the study: Actinidia spp. (kiwi tree) and Malus spp. (apple tree). These two species are currently the most representative of the Cuneo area and they cover a surface of 4454 ha and 3482 ha, respectively (ISTAT, 2010).

In the case of the apple tree, two different pruning techniques, traditional and taille longue, were compared (Table 1).

The traditional pruning system used in the Cuneo area is usually applied to the fusetto (Figure 1) training system, in which the plant takes on a typical conical shape with shoots tending to develop at toward the base of the trunk (basitony). Management of the production load and shape maintenance are adjusted with pruning to select for shortened branch fruiting (Diemoz, 2005).

Taille longue pruning system, devised by French researcher Jean Marie Lespinasse, was first adopted in Cuneo in the late 1980s and early 1990s. It is usually applied to training systems called free growth because it does not have a hierarchical branch arrangement within the canopy (Figure 1). The technique results in rapid production entry, vigour status regulation, vegetation and production balance, and fruit homogeneity (Musacchi et al., 2011; Diemoz et al., 2003). Plants bred with this system have an axial shape and a tendency to develop freebearing (acrotony) summit branches. Fruit-bearing branches, bent below the horizontal and never shortened, are inserted along the entire central axis (Diemoz, 2005) (Figure 2).

The apple tree trial compared four different varieties: Gala, Scarlett,

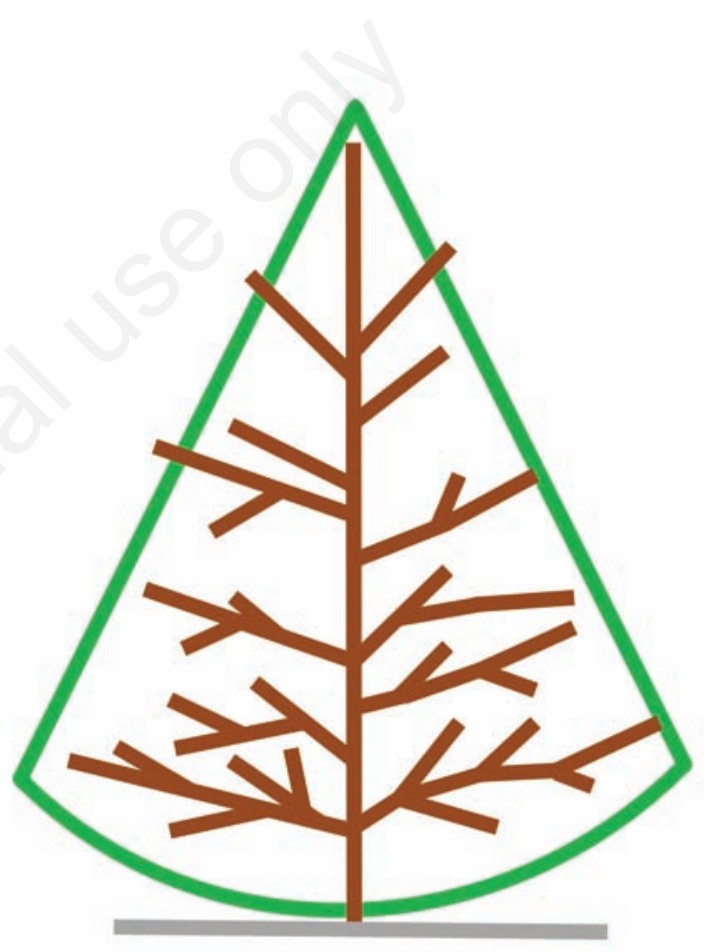

Figure 1. Conical structure of plant with shoots tending to develop at or toward the base of the trunk (basitony).

Table 1. Technical characteristics of the experimental orchards under investigation.

\begin{tabular}{|c|c|c|c|c|c|c|c|c|c|c|c|}
\hline Farm & Species & Variety & $\begin{array}{l}\text { Plant } \\
\text { year }\end{array}$ & Rootstock & $\begin{array}{l}\text { Row } \\
\text { spacing }\end{array}$ & $\begin{array}{l}\text { Spacing between } \\
\text { trees on the row }\end{array}$ & $\begin{array}{c}\text { Density } \\
\text { plant }\end{array}$ & $\begin{array}{l}\text { Coltivation } \\
\text { technique }\end{array}$ & $\begin{array}{l}\text { Pruning } \\
\text { technique }\end{array}$ & $\begin{array}{l}\text { Apple } \\
\text { (Mg }\end{array}$ & $\begin{array}{l}\text { eld } \\
-1)\end{array}$ \\
\hline & & & & & & & & & & First quality & Factory \\
\hline B & Kiwi & Hayward & 2004 & I & 4 & 4.5 & 556 & Arbor & Peyracchia & $236-262$ & I \\
\hline 0 & Kiwi & Hayward & 1988 & 1 & 4 & 4 & 625 & Arbor & Peyracchia & $236-262$ & l \\
\hline B & Apple & Scarlett & 1999 & M9 PAJAN2 & 4 & 1 & 2500 & Free growth & Taille longue & 631 & 23 \\
\hline B & Apple & Gala & 1999 & M9 & 4 & 1 & 2500 & Free growth & Taille longue & 583 & 21 \\
\hline B & Apple & Ambrosia & 2007 & M9 & 3.8 & 1 & 2632 & Free growth & Taille longue & 695 & 14 \\
\hline 0 & Apple & Gala & 2003 & M9 & 4 & 1.3 & 1923 & Fusetto & Traditional & 346 & 86 \\
\hline 0 & Apple & Golden & 1990 & M26 & 4 & 2 & 1250 & Fusetto & Traditional & 544 & 60 \\
\hline
\end{tabular}


Ambrosia, and Golden (Table 1). The first three varieties were from rootstock M9 (newest orchards); the fourth was M26 rootstock (oldest orchard) (Table 1). In recent years, the range of apple rootstocks has been reduced to M9 and just a few others. This restriction, uncommon in other fruits, came about through the association of rootstock M9 (Figure 3) with modern apple farming because of its dwarf tree, strong vigour containment, rapid fruit-bearing induction, enhanced production efficiency, and product quality. No other known rootstock can present all of these characteristics together (INEA, 2000).

To verify the potential effect of plant age on biomass production, orchards of various ages were compared (Table 1). Crop age (Table 1) was considered a variable only for kiwi tree due to the facts that Hayward is currently the main cultivated variety and the most widespread training system is the arbor system.

Nearly all kiwi orchards are managed with the Peyracchia pruning system. First used in the early 1990 s, the system evolved from traditional kiwi pruning, particularly in its choice of productive branches. The system has also had effects beyond pruning. Specifically, the system has contained the vigour that had previously characterised the kiwi plant by decreasing the nutrient contribution and amount of water distributed, especially from late July onwards. These effects made modification of the pruning system possible so that it was no longer based on renewal formation, but on maintaining a correct balance between old wood and new branches.

Yield $\left(\mathrm{Mg} \mathrm{ha}^{-1}\right)$ was calculated for each species, variety, and planting year from measurement of the pruning residual mass (Mg) and collecting surface (ha). The basal diameter ( $\mathrm{mm}$ ) of each pruned branch was also measured and classified.

Surveys were performed on row spacing portions, at distances of over 10 metres from plot sidelines, and away from plot boundary rows to reduce potential edge effects (Figure 4). These guidelines led to different numbers of tree samples based on survey area spacing and available sampling activity surface area $\left(\mathrm{m}^{2}\right)$, such that 4 half kiwi trees (32.0-36.0 $\mathrm{m}^{2}$ of survey surface area) and 10-20 half apple trees (36.0$41.6 \mathrm{~m}^{2}$ of survey surface area) made up the various survey areas. Samples were collected with three replicates randomly distributed for each orchard species and variety.

Quantification of the cut material inside the survey area was made after manual harvest by weighing branches grouped into classes according to diameter ( $5 \mathrm{~mm}$ increments). The $5 \mathrm{~mm}$ width increment was chosen because it is practical both as a description of pruning material, and for classification and description of branches lost in round baling during harvest. The weight was determined by digital dynamometer (Sicutool SCU 4488B) with an accuracy of 0.02 Newton $(\mathrm{N})$; basal diameters were measured with a mechanical Vernier calipers calibrated in twentieths (Valex_1800308).

Biomass production was estimated by analytical calculation based on the weight of individual survey area material extended to total crop area and expressed as dry matter per unit area $\left(\mathrm{Mg} \mathrm{DM} \mathrm{ha}^{-1}\right)$. The dry matter content of the pruning residues was described as the difference in weight of fresh material and dried material after approximately $24 \mathrm{~h}$ at $103^{\circ} \mathrm{C}$ in a forced ventilation oven (Controls D1396-10).

Wood humidity was defined as the ratio between the water quantity in a piece of wood and its weight (anhydrous or wet). When referring to an anhydrous state, humidity is expressed according to the following formula:

$$
\mathrm{H}_{\text {anhydrous }}=\left[\left(\mathrm{M}_{\text {wet }}-\mathrm{M}_{\text {anhydrous }}\right) / \mathrm{M}_{\text {anhydrous }}\right] * 100
$$

When referring to the wet state, the formula is:

$$
\mathrm{H}_{\text {wet }}=\left[\left(\mathrm{M}_{\text {wet }}-\mathrm{M}_{\text {anhydrous }}\right) / \mathrm{M}_{\text {wet }}\right] * 100
$$

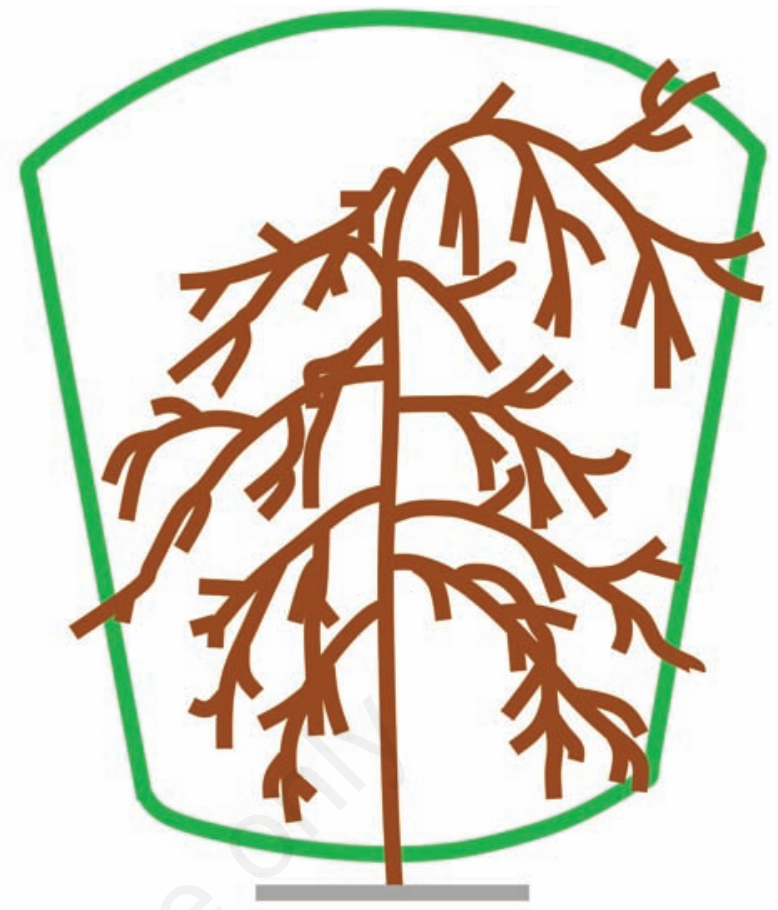

Figure 2. Cylindrical structure of top branch accentuation (acrotony).

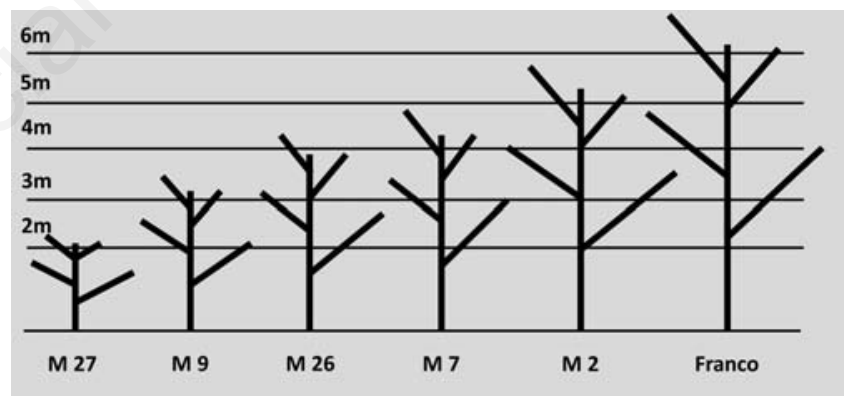

Figure 3. Vigour of apple rootstocks $M$.

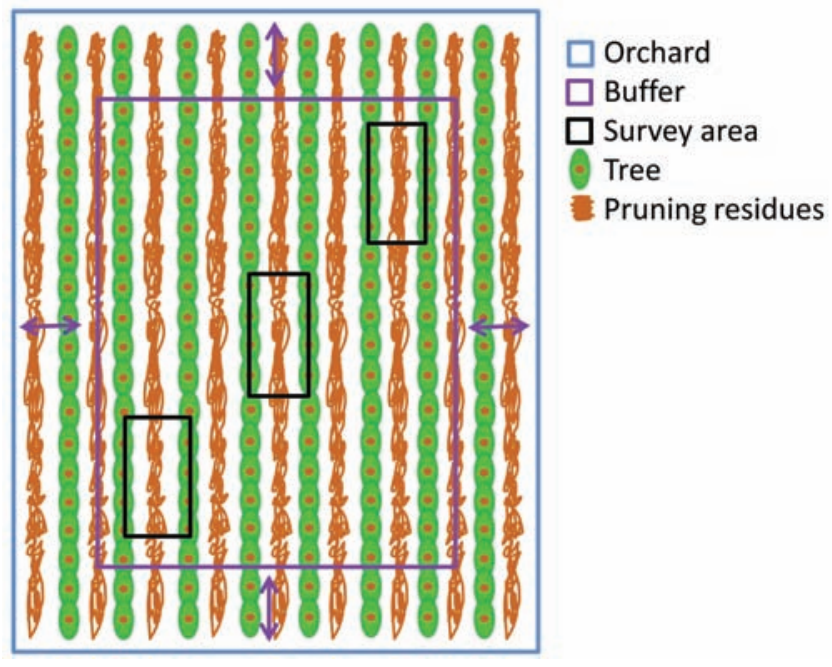

Figure 4. Experimental plot design. 
To quantify the real harvestable biomass for each orchard species and variety, the material was appropriately grouped in swaths through a rake (GIRORAMI new $8 \mathrm{BC}$ ) and subsequently harvested by a fixedchamber forage round baler (Lerda 135) (Table 2). The round baler had been previously modified to make biomass bales of approximately 0.5 megagrams of raw material under 150 bars of pressure in the compression chamber.

The fixed chamber round baler produced same-sized cylindrical bales $(1220 \times 1350 \mathrm{~mm})$, equal to a volume of $1.75 \mathrm{~m}^{3}$. The average weights of kiwi and apple pruning residue bales were computed after weighing 17 and 9 bales, respectively. Kiwi bales averaged $484.4 \mathrm{~kg}$ (SD 35.7 ) with a density of $277.5 \mathrm{~kg} / \mathrm{m}^{3}$, while those of apple averaged 493.5 $\mathrm{kg}$ (SD 23.5) with a density of $282.7 \mathrm{~kg} / \mathrm{m}^{3}$; all data refer to raw material. Harvest losses, harvested by hand, were calculated following the same experimental design (Figure 4) and with the same methodology described above for the quantification of total biomass production (survey area differed according to tree spacing).

\section{Results}

\section{Analysis of diameter classes}

The collected data showed that kiwi trees had larger basal diameter

Table 2. Technical specifications of Lerda T135 round baler.

\begin{tabular}{ll} 
Technical specification & \\
Maximum length & $3900 \mathrm{~mm}$ \\
Maximum width & $2380 \mathrm{~mm}$ \\
\hline Maximum width picker & $1500-1850 \mathrm{~mm}$ \\
Weight & $1950 \mathrm{~kg}$ \\
\hline Power required & $55 / 65 \mathrm{hp}$ \\
Bale length & $1350 \mathrm{~mm}$ \\
\hline Bale diameter & $1220 \mathrm{~mm}$ \\
Implement type & 2 rotating rakes alongside pick-up \\
& Strengthening of the mechanical parts \\
\hline Tractor power & $58 \mathrm{~kW}$ \\
Operating speed & $4.5 \mathrm{~km} / \mathrm{h}$ \\
\hline Number of operators & 1 \\
\hline
\end{tabular}

branches than apple trees (Figure 5). A different diameter class distribution was also found for the different apple tree pruning systems. In the taille longue system, over $90 \%$ of the samples fell into the first two diameter classes, while most branches (95\%) in the traditional system were distributed among the first three classes.

In fact, the traditional pruning system reflected greater plant vigour, which promoted branch production of greater diameters; the taille longue system produced lower woody biomass due to fewer cut-off branches of smaller diameter.

\section{Analysis of the amount of biomass produced}

To make comparison easier, biomass production among the various species and varieties was expressed as dry matter (Table 3). Results were similar to those observed in the cut branch diametric analysis, i.e. biomass yield (Figure 6) was strictly related to the adopted pruning system. Biomass yields averaged $0.46 \mathrm{Mg} \mathrm{DM} \mathrm{ha}^{-1}(\mathrm{SD}=0.36)$ in the taille longue system versus $3.04 \mathrm{Mg} \mathrm{DM} \mathrm{ha}^{-1}(\mathrm{SD}=1.18)$ in the traditional system. Within the apple trees pruned by taille longue techniques, the variety that registered the lower biomass yield $\left(0.10 \mathrm{Mg} \mathrm{DM} \mathrm{ha}^{-1}, \mathrm{SD}\right.$ 0.02) was the variety Ambrosia while the highest biomass yield was achieved with the variety Gala (0.83 $\mathrm{Mg} \mathrm{DM} \mathrm{ha}^{-1}$, SD 0.16) (Figure 7). Intermediate values were obtained with the variety Scarlett $(0.44 \mathrm{Mg}$ $\mathrm{DM} \mathrm{ha}^{-1}$ and SD 0.09). With the traditional pruning system, apple tree production was an average 4.5 times higher than the taille longue prun-

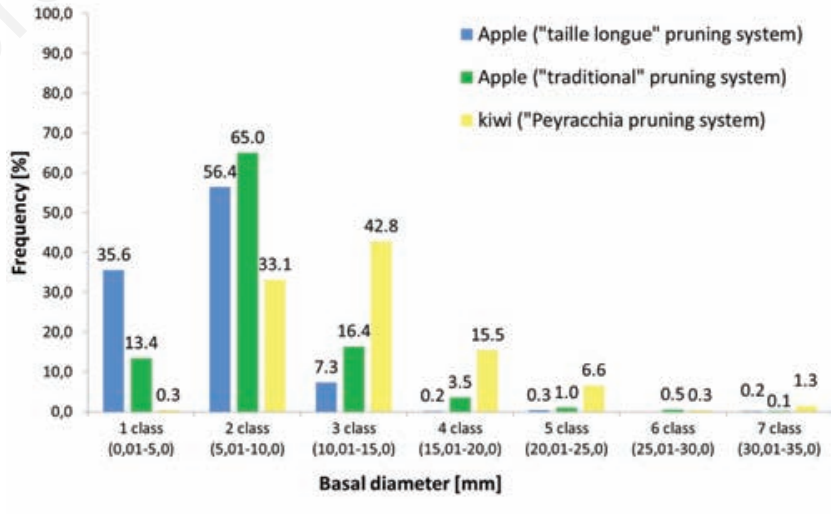

Figure 5. Frequency of pruning branches for basal diameter class as a function of different pruning systems.

Table 3. Humidity content of pruning biomass (anhydrous and wet).

\begin{tabular}{|c|c|c|c|c|c|c|}
\hline Species & Variety & Plant year & $\mathrm{H}_{\text {anhydrous }}(\%)$ & SD $\mathrm{H}_{\text {anhydrous }}(\%)$ & $\mathrm{H}_{\text {wet }}(\%)$ & SD $H_{\text {wet }}(\%)$ \\
\hline Kiwi & Hayward & 2004 & 108.09 & 4.34 & 51.93 & 1.00 \\
\hline Kiwi & Hayward & 1988 & 121.96 & 3.09 & 54.94 & 0.63 \\
\hline Apple & Scarlett & 1999 & 67.59 & 0.64 & 40.33 & 0.23 \\
\hline Apple & Gala & 1999 & 89.04 & 3.32 & 47.09 & 0.93 \\
\hline Apple & Ambrosia & 2007 & 64.97 & 0.18 & 39.38 & 0.07 \\
\hline Apple & Gala & 2003 & 100.4 & 1.52 & 50.1 & 0.38 \\
\hline Apple & Golden & 1990 & 83.12 & 1.57 & 45.39 & 0.47 \\
\hline
\end{tabular}

$\mathrm{H}$, humidity; SD, standard deviation. 
ing system. The highest biomass production was obtained with the apple tree variety Golden with $3.87 \mathrm{Mg} \mathrm{DM} \mathrm{ha}^{-1}$ (SD 0.12) while the lowest was obtained with the variety Gala (2.21 $\mathrm{Mg} \mathrm{DM} \mathrm{ha}^{-1}$, SD 0.61).

For the kiwi tree, the biomass yield was an average $2.51 \mathrm{Mg} \mathrm{DM} \mathrm{ha}{ }^{-1}$ (SD 0.83), very close to that found for the apple tree pruned with the traditional system.The kiwi plants of year 2004 produced $3.10 \mathrm{Mg} \mathrm{DM} \mathrm{ha}^{-1}$ (SD 0.49) of biomass corresponding to $+37.9 \%$ when compared to the biomass yield of the plants of year 1988 (1.93 $\mathrm{Mg} \mathrm{DM} \mathrm{ha}^{-1}$, SD 0.21).

\section{Analysis of harvest losses}

When the taille longue pruning system was used, an average of $47 \%$ of pruning residues were lost at harvest (Figure 8). Alternatively, harvesting losses recorded with traditional pruning were considerably lower (average 11\%). Harvesting losses for the apple variety Ambrosia were $95 \%$, which related to its conformation of very straight, small basal diameter, limited length pruned branches (Figure 9). All the other apple varieties resulted in maximum harvesting losses of $41 \%$ for orchards pruned by taille longue and $13 \%$ in orchards pruned by the traditional system. The traditional pruning system showed very similar harvesting losses regardless of the apple tree variety considered.

Kiwi tree harvesting losses were approximately $19 \%$ of the available biomass (Figure 8).

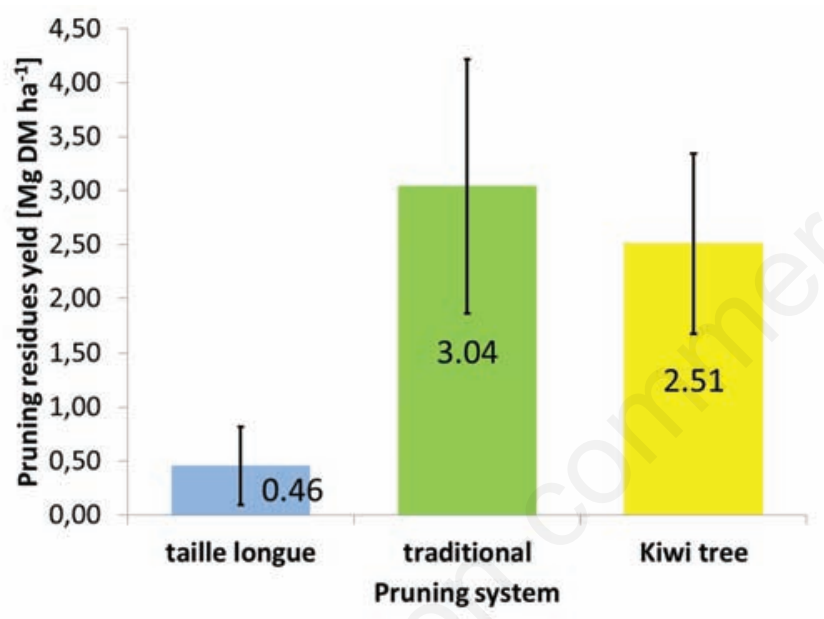

Figure 6. Average yield of pruning residues as a function of different pruning systems.

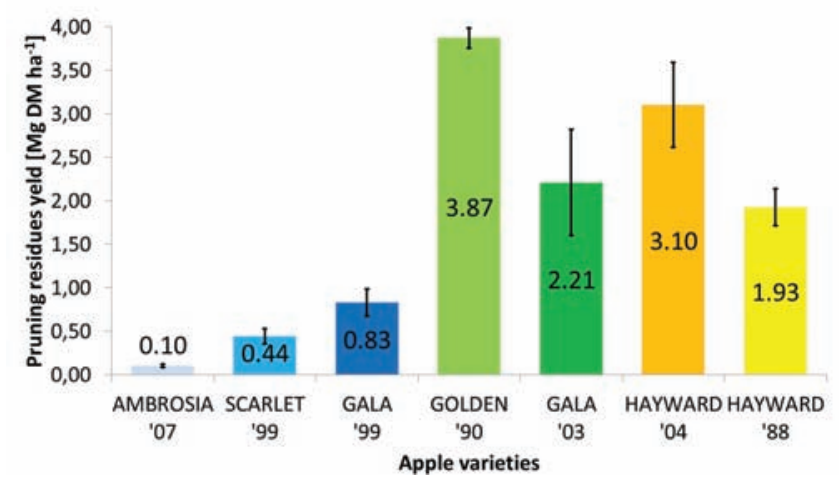

Figure 7. Average yield of pruning residues for each species, variety and plant year.

\section{Conclusions}

The processed data showed that both the apple tree and kiwi tree, even if affected by the vigour-limiting bacterial canker Pseudomonas syringae pv. actinidiae (Balestra et al., 2009; Renzi et al., 2012), produced good biomass amounts when pruned with the traditional pruning technique (2.5 and 3.0 $\mathrm{Mg} \mathrm{DM} \mathrm{ha}^{-1}$, respectively). However, harvesting the potential biofuel with the described pruning techniques was extremely difficult and considerable biomass was lost in the process (10-95\% of residues according to species, variety, and pruning technique).

Furthermore, the experiment highlighted how the pruning system adopted for the apple tree (traditional or taille longue) can have a substantial effect on biomass yield, on the cut-off branch basal diameter, and on harvest losses.

Although some orchards are still grown with the traditional pruning system, future projections suggest abandonment of the traditional pruning system in favour of the new taille longue pruning system. It ensures higher quality fruits (Diemoz et al., 2003) with fewer pruning residues (-80\%) and a concommitant lower management cost for the farm. In the analysis of a possible supply chain aimed at turning prun-

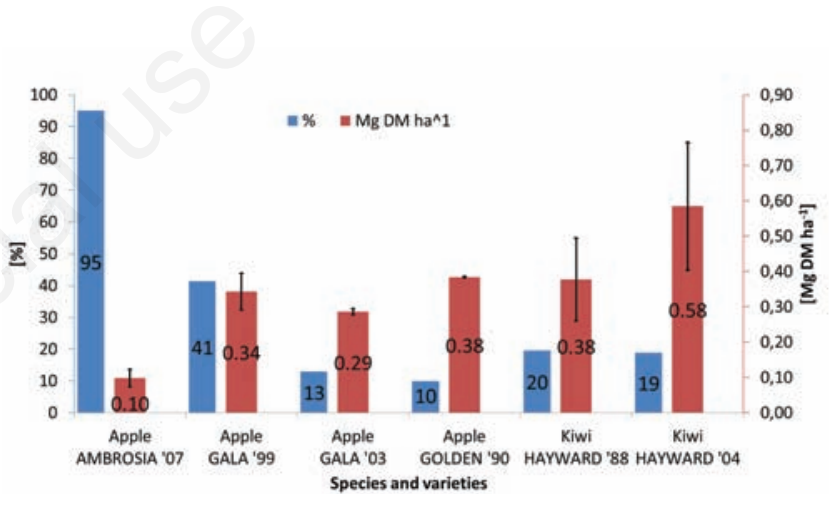

Figure 8. Harvest losses expressed as dry matter $\left(\mathrm{Mg} \mathrm{DM} \mathrm{ha} \mathbf{D a}^{-1}\right)$ and as a percentage of total biomass produced.

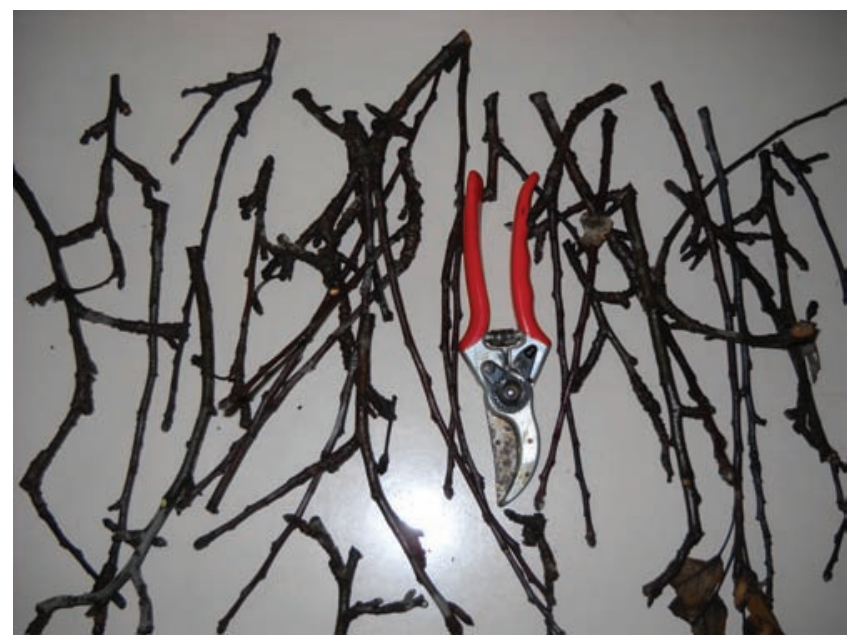

Figure 9. Pruned branches of apple var. ambrosia. 
ing residues into biofuel, consideration must be given to the technical evolution that underlies the consistent reduction in available orchard pruning biomass. For the kiwi tree, the potential destruction of all bacterial canker-affected plants must be considered since none is immune to the disease.

Finally, in the absence of a focused survey, there is some evidence to suggest that the harvest losses in variety Ambrosia apple trees (most advanced orchards in all respects) are due to the pruned branch conformation of the taille longue pruning system and are characterised by a small diameter $(<15 \mathrm{~mm})$, high straightness, and limited length $(<300$ $\mathrm{mm}$ ). There was also some evidence in the kiwi trees that harvesting losses are due primarily to the straightness of the branches that are not compatible to mechanical round baler harvest systems. Further investigation and analysis of the specific conformation of the pruned branches (length and straightness), and the impact of the latter on the loss of harvest, is required. In this regard, optimisation of the harvesting machines must target harvest branches of small basal diameters (max. $15 \mathrm{~mm}$ ) and high straightness. Biomass with these characteristics cannot be successfully harvested by traditional pick-ups fitted to the usual fodder round balers.

\section{References}

Balestra G.M., Mazzaglia A., Quattrucci A., Renzi M., Rossetti A. 2009. Current status of bacterial canker spread on kiwifruit in italy. Austr. Plant Dis. Notes 34:36-4.

Biomasse Italia S.p.A. 2008. La filiera da arboricoltura da legno a ciclo breve (S.R.F.) per Biomasse Italia S.p.A. Available from: http://www.biomasseitalia.it/Download/SRF_Presentazione.pdf Accessed: May 2013.

Centro Nazionale delle ricerche (CNR). 2012. Progetto "Filiera dell'energia da biomassa". Available from: http://www.agroenergia.net/ images/stories/FEB/1_report.pdf Accessed: May 2013.

CESTAAT. 1990. Impieghi dei sottoprodotti agricoli e agroindustriali. Vol. 1. Centro Studi sull'Agricoltura, l'Ambiente e il Territorio (CESTAAT), Roma, Italy.

Cotana F., Calavaglio G. 2008. La valorizzazione energetica delle potature di olivo. Available from: http://www.crbnet.it/File/ Pubblicazioni/pdf/1476.pdf Accessed: December 2013.

CReSO, 2011. La batteriosi del Kiwi in Piemonte: ricerca e sperimen- tazione. Available from: http://multidata.multiwire.net/upload/gesnew/CresoRicerca_722emb_04.pdf Accessed: August 2013.

Diemoz M. 2005. Allevamento del melo: il solaxe e la "conduite centrifuge". Institut Agricole Régional, Aosta, Italy.

Diemoz M., Vittone G., Pantezzi T. 2003. Potatura del melo: possibili evoluzioni. Terra Trentina 1:21-3.

ENAMA. 2011. Studio progetto biomasse ENAMA. Available from: http://www.enama.it/it/biomasse_studio.php Accessed: May 2013.

ENEA. 2010. Atlante delle biomasse. Available from: http:/www.atlantebiomasse.enea.it/Accessed: May 2013.

Istituto Nazionale di Economia Agraria (INEA). 2000. Available from: http://inea.it/isfcaserta/listevarietali/melo.html Accessed: August 2013.

Isitituto Nazionale di Statistica (ISTAT). 2010. Available from: http://dati-censimentoagricoltura.istat.it/ Accessed: May 2013.

Italian Biomass Association (ITABIA). 2005. Disponibilità, caratteristiche e mercato delle biomasse in Italia. Available from: http:/www.itabia.it/conoscenza.php Accessed: May 2013.

Manzone M. 2006. Meccanizzazione degli impianti di biomassa legnosa a rapido accrescimento (SRF) per la produzione di energia. $\mathrm{PhD}$ Diss., Università di Torino, Italy.

Musacchi S., Colombo R., Mariani M. 2011. Impiantistica e vivaismo. Available from: http://www.crpv.it/doc/44806/DLFE-1402.pdf Accessed: May 2013.

Quadretti R. 2013. CReS0 di Manta (CN): il punto sulla batteriosi dell'actinidia in Piemonte. Available from: http:/www.freshplaza.it/ article/53642/CReS0-di-Manta-(CN)-il-punto-sulla-batteriosi-dellactinidia-in-Piemonte Accessed: August 2013.

Regione Piemonte. 2013. Lotte obbligatorie e misure d'emergenza Batteriosi dell'actinidia Pseudomonas syringae pv. Actinidiae. Available from: http:/www.regione.piemonte.it/agri/area_tecnico_ scientifica/settore_fitosanitario/vigilanza/batteriosi.htm Accessed: August 2013.

Renzi M., Copini P., Taddei A.R., Rossetti A., Gallipoli L., Mazzaglia A., Balestra G.M. 2012. Bacterial canker on Kiwifruit in Italy: anatomical changes in the wood and in the primary infection sites. Phytopathology 102:827-40.

Tyson J.L., Rees-George J., Curtis C.L., Manning M.A., Fullerton R.A. 2012. Survival of Pseudomonas syringae pv. actinidiae on the orchard floor over winter. N. Zeal. Plant Protect. 25:28-65. 